\title{
FOOD SCIENCE AT THE UNIVERSITY OF LEEDS
}

\author{
By Prof. A. G. WARD, O.B.E. \\ Department of Food and Leather Science
}

$\mathrm{O}^{\mathrm{N}}$ June 18, Mr. Lauchlan Rose, chairman of the Food Manufacturers' Federation, formally opened the extension to the Procter Department of Food and Leather Science of the University of Leeds. The name commemorates Prof. H. R. Procter, who founded, in 1891 , the Leather Industries Department, the precursor of the present one. The additions constitute an increase in floor area of almost 50 per cent to a total of more than 18,000 sq. ft. They provide much-needed facilities for the 4-year course leading to the honours B.Sc. in food science, the inaugural year of which is just about to be completed, as well as for postgraduate research in food scienco.

Apart from offices, the main part of the extension is devoted to the food technology laboratories under the direction of Mr. G. Glew. The purpose of these laboratories is two-fold: first, to enable undergraduate students to handle small-scale equipment in order to obtain an understanding of the operations involved in food processing and, secondly, to provide facilities for research into technological problems of the food industry by undergraduates in their final year, research students, and members of the staff. The facilities of the laboratories include three refrigerated chambors, one controllable down to $-29^{\circ} \mathrm{C}$, a. blast freezer, a small Leybold-Elliott freeze drier, a Kestner laboratory spray drier, a Kestner drum drier, and a Q.V.F. all-glass concentrator with a flavour recovery unit, together with a canning line and a variety of equipment for mixing, milling, baking, boiling and testing.

Attached to tho laboratories is a room for bacteriological control work, much of which is carriod out in collaboration with Mr. J. Wolf's Bacteriology Section of the Department of Agriculture. This work was illustrated by several exhibits.

Dr. R. Re日d's electron-microscopy group with its Siemens Elmiskop II and a full range of ancillary equip- ment, including two ultramicrotomes, an ultrasonie disintegrator, and a metal shadowing unit, has been re-housed in the extension in a compact suite, and light microscopy, under Dr. F. Olga Flint, is catered for both on the undor- and post-graduste levels. A Leitz 'Ortholux' microscope has just been acquired. The Biochemistry Research Laboratory's most prized piece of equipment is a Technicon automatic analyser, at present used for amino-acids, but shortly to be used on carbohydrates as well. A physics research laboratory and a final-year undergraduate laboratory complete the extension.

The previous addition to the Department in 1959 enabled facilities, such as a Spinco model $L$ ultra-centrifuge, a Bellingham and Stanley photoelectric spectropolarimeter, and a light-scattering apparatus, to be installed. The present occasion provided the opportunity to add a Perkin-Elmer 237 infra-red spectrophotometer and a 451 gas chromatograph.

In connexion with the opening, the whole department as well as the new oxtension remained on view for throe days, and some two hundred visitors were received. Special food scionce exhibits illustrated the methods adopted for undergraduate teaching and these included a display by Dr. R. Harper of the Psychology Department, who is responsible in the course for treating problems of percep. tion with special reference to the sensory qualitios of foods and food acceptance. A further display, on the history of the Public Analyst's work, was that by the City Analyst, Mr. R. A. Dalley, who lectured on food control aspects.

Present research on view included topics such as the electron microscopy of wheat gluten, the gelling of gelatin and poctin gels, and the isolation of the components of black-currant volatiles.

\section{THE SOUTH-EASTERN UNION OF SCIENTIFIC SOCIETIES}

\section{ANNUAL CONGRESS}

$\mathrm{A}^{\mathrm{T}}$ $T$ the invitation of the Mayor and Corporation of Tunbridge Wells and the Tunbridge Wells Natural History Society, the South-Eastern Union of Scientific Societies held its sixty-eighth annual congress at Tunbridge Wells during May 9-12 under the presidency of Dr. W. S. Bristowe. The headquarters of the Congress was at the Public Library and Museum; the Young Naturalists' evening was held at the County Grammar Schools for Girls, by permission of the Headmistress.

The delegates were welcomed and entertained by the Mayor, Alderman Donald Savage, who reminded them that the Union was founded at Tunbridge Wells in 1896 , only seven years after the town received its Charter. The Corporation takes great pride in its Museum, one of the first to stress the importance of local interest in the display of exhibits.

At the commencement of the Congress, the delegates were conducted on a tour of the town by Mrs. E. Bradley, who, on the route, deseribed the Georgian houses and their past tenants, the origin and devolopment of the Walks, now the Pantiles, and the cures (real and imaginary) obtained by taking vast quantities of the water from the chalybeate springs. Messrs. Boots kindly permitted the examination of the famous bath beneath the floor of their premises. A visit was made to the Church of King Charles the Martyr, where the change in its orientation was dis. cussed.

A Young Naturalists' evening was held, and questions on a wide variety of natural history topics were answered by $a_{\text {team }}$ of experts under the chairmanship of Maxwell Knight, prizes being awarded to the girl and boy who submitted the best questions.

After the formal induction to the presidency, Dr. W. S. Bristowe delivered his address on "A Galaxy of Spiders". He commenced by saying how easy it was for a collector in towns to be suspected of misdemeanour. He had been disgraced near Hyde Park Corner where, seeing a prim and proper lady in distress, because of a spider hanging on a thread from her hair, he had removed it, opened his mouth and popped it in. The lady's expression of extreme disgust later became good-humoured. During his visit to Thailand he could not, at first, regard the delicacy of spiders with favour, but, when the feeling of repugnance was overcome, he found they tasted well. Discussing this with a Siamese gentleman, who had, attended school in England, the same feeling had occurred when he was asked to eat British green raw vegetables and the decaying carcases of pheasants and hares. 
As food, spiders are not poisonous and were used for medicine in early times. He instanced the case of Dr. Muffet's daughtor, born 1540, who was treated for all ailments, internal and external, with concoctions of spider. It is possible from this the nursery rhymo of "Little Miss Muffet" evolved.

Throughout the ages human beings have had two reactions to spiders, admiration and fear. A protective mythology throughout the world still causes people to dislike killing spiders, and, in European countries, it is considered lucky to have them alight on one's clothes, a notion originating with the Greeks.

Spiders are of ancient stock, occurring in Carboniferous deposits perhaps 350 million years ago, and, in Asia, some eight species of living 'fossils' survive. Flies appeared. 100 million years after spiders, and the first spiders fed on crawling things. These probably evolved wings to enable the avoidance of capture, then spiders spun nets to catch the flying insect; some insects then developed armour (beetles) through which tho spider could not penetrate, some became distasteful and hundreds of species of spider would not eat them at all, and what may be described as an evolutionary battle was carried on. The spider population is enormous, millions per acre, and the weight of insects eaten every year is more than the weight of all the people in England. They are good at dispersing themselves, floating in the air on self-woven parachutes; Dr. Bristowe had found four species of spider on a remote arctic island. Although they had nothing corresponding to human intelligence, they had something equally remarkable, the knowledge of how to react.

In studying the mating habits, it is convenient to divide them into three groups: (1) long-sighted; (2) shortsighted; (3) webbed. In the long-sighted group the males are more fragile than the female and decoration has evolved and is displayed to attract the female. The shortsighted males use special grips, sometimes in the jaws, to ensure that once in contact with the female they must not lose her, in case they cannot find her again. The webbed type are rather like the long-sighted and also use a sort of 'Morse code' to attract the female, being able to pass sounds, as vibrations, along the strands of their webs.

The Archæological Section of the Union was addressed by the president, James Money, on "The Iron Age Hill Fort at High Rocks". He spoke of excavations he had carried out, under the auspices of the Sussex Archæological Society, of rock shelters and the fort, mentioning the help science can give to archæology which, in turn, can help science. Charcoal from the rock shelters had been examined by Miss Balfour Browne at the British Museum (Natural History) and the pollen analysis was carried out by Dr. G. W. Dimbleby at the University of Oxford.

The rock shelters were overhanging rocks on the escarpment of the Tunbridge Wells Sand (Lower Cretaceous) and the flint implements found indicated they were occupied during Mesolithic and Neolithic times, ranging approximately from 6000 B.c. to 1800 B.c. There were hearths of sandstone, heavily burnt, and examination of the charcoal confirmed the age arrived at by the artefacts.

At the fortified Iron Age camp, excavation revealed an area of 20 acres protected by double ramparts and ditches, the ramparts made of stone and earth, numerous postholes showing the defences were strengthenod by a timber palisade. A few fragments of pottery were found of the Southern $2 b$ and $1 c$ types. The outer ramparts were built in the second century B.c. by Wealden inhabitants to repulse the invasions of Belgic people from northorn France and Belgium. The inner defences were constructed at the beginning of the first century A.D., and the finds included iron-ware, the upper part of a rotary quern of local sandstone and a fragment of Roman Samian ware. Evidence of agriculture on the site consisted of pollen grains of wheat; a number of hearths, some with layers of charcoal 6 in. thick, were discovered $15 \mathrm{in.} \mathrm{below}$ ground-level. Extensive excavation has been carried out at the east entrance, revealing triple fortifications, a paved pathway and an ancient trackway.

The president of the Zoological Section, Prof. H. R. Hewer, chose as the title of his address "Seals". He said he proposed to speak mainly about the grey seals as, during the past ten years, our knowledge of them had greatly increased, for in a book published in 1926, of twenty-six statements regarding them, twenty-two were completely wrong. The methodical examination commenced in 1950 off the coast of west Wales, for the matter had become a political issue through the complaints of depreciation caused by seals from fishermen of north-east England and south Scotland. The matter is now taken seriously, and a responsible officer, J. Smith, of the Nature Conservancy, is stationed in tho Orkneys, where the largest colony in the British Isles occurs; as many as 3,000 cubs are born each year. A variety of interests calls for control of a large natural population. When an area is completely protected there is a danger from epidemies and the death-rate increases - the mortality-rate rises to 35 per cent in the first few days of their life. The cubs during the first fortnight of their lives increase in weight from 35 to $90 \mathrm{lb}$., mostly in blubber, and should a cub leave the breeding ground before reaching this weight it will not survive. Not a single young seal of the hundreds either shot or caught in nets, by people interested in the salmon fisheries, weighed more than $70 \mathrm{lb}$. In a colony of 1,000 of each sex, a thousand cubs would be born if all the cows became pregnant, and as the cows, on average, live 35 years and the bulls 25 years, controlled preservation is necessary if the colony is to be successfully established. Age is determined by the examination of thin sections, transverse and longitudinal, of the teeth. The weight of the bull must be considerable when it reaches the breeding territory, for it is without food for 6-8 weeks, living on its blubber. The territory of each bull is vigorously guarded against invasion by other bulls, and there are 7-10 cows to each bull; a specimen bull measured 90 in. in length and weighed about a quarter of a ton. Bulls mature in six years and cows in five years; cubs are produced in the following year. Prof. Hewer concluded his address with a commentary on a film he had taken on the Island of Shillay.

Dr. R. Casey, as president of the Geological Section, gave an address on "The Dawn of the Cretaceous Period in Britain". He said that from time to time some new find throws light on an obscure geological problem and permits reassessment of a boundary, such as the one he proposed to discuss, the Jurassic-Cretaceous. Across northern Europe are signs of concerted movements of the sea which indicate a natural starting point of the Cretaceous period. This affects ideas of the geography of Britain in remote times and on the grouping of the strata.

Three separate basins received deposits spanning the Jurassic-Cretaceous boundary: (1) Southern (KentDorset-Bucks.); (2) Spilsby (Lincolnshire-Norfolk); (3) Speeton (Yorkshire). The ammonites of the Spilsby Sandstone show there is no missing interval in the Jurassic marine record in Britain. Genera of ammonites which occur in the Portland of southern England and the Volgian of the U.S.S.R. are also in the lower part of the Spilsby Sandstone. Dr. Casey traced the development through the Portland-Purbeck regression and the incoming Cretaceous tide and said that the Cinder Bed makes a firm datum. He suggested that the advancing Cretaceous sea re-opened the connexion between the Spilsby and Southern basins, flooding the Purbock swamps and laying the Cinder Bed as the bedrock of the Cretaceous system in southern England; evidence from continental Europe confirmed this view. In conclusion, Dr. Casey said that all lines of evidence lead to the idea that a single advance of the sea initiated the Cretaceous Period in northern Europe, and to overcome nomenclature difficulties he would suggest 'Lulworth Beds' for the sequence 
between the Portland Stone and the Cinder Bed, and 'Durlston Beds' for the sequence from the base of the Hastings Beds down to, and including, the Cinder Bed; the former grouped with the Portland Beds, the latter a subordinate and basal division of the Wealden Beds.

Favourable weather enabled the full excursion programme to be carried out: the botanists visited High Rocks and Eridge, the archæologists were conducted to the Rock Shelters and Iron Age camp at High Rocks by
J. Money, while the geologists examined beds within the Wealden, in the vicinity of Tunbridge Wells, under the direction of Dr. R. Casey, who dealt especially with the relation between the Wadhurst Clay and the Tunbridge Wells Sandstone.

The excellent arrangements for the Congress were undertaken by the Tunbridge Wells Natural History Society, for whom Mrs. D. Vernede acted as honorary secretary.

F. J. Eprs

\section{THE MATHEMATICAL ASSOCIATION}

\section{ANNUAL CONFERENCE}

$\mathrm{T}$ HE Mathematical Association's annual conference held at the University of Nottingham in April was outstanding for the high level of interest sustained throughout the sessions. The Association's membership continues to rise steadily and now stands at more than 5,000 .

In his report on current affairs. Mr. Combridge spoke of the formation of the Joint Mathematical Council of the United. Kingdom which was announced in the Press on April 3. The Council has set up a fact-finding committeo to investigate proposals for setting up an Institute of Mathematies.

The Conference on Mathematics in Education and Industry, of which Mr. Combridge is chairman, had held a meeting on March 23 and had adopted the report of its working party. This report was being abbreviated into a pamphlet which he hoped would be circulated to members of the Mathematical Association this summer. The Conference gave its blessing to a schome put forward by Mr. B. T. Bellis of Highgate School to form a group of schools which would form links with industry which might assist, in particular, with the teaching of mathematics in the later years of school. Mr. Combridge emphasized the noed for strengthening the links between schools and industry, and between schools and training colleges and departments of education.

\section{The Universe}

In his presidential address, Prof. V. C. A. Ferraro reviewed the advances made in our knowledge of the universe since Galileo first directed, his newly mado telescope to our nearest neighbours in space. Galileo's discovery of the satellites of Jupiter demolished the last remaining vestiges of the Ptolemaic system. Then followod the rise of descriptive astronomy associated with the remarkable researches of Sir William Herschel, who stressed the need to build large telescopes for a better understanding of the architecture of the universe. $\mathrm{He}$ also suggested, with remarkable insight, that the problem of the Milky Way might be resolved by supposing that the stars extended much farther into space along the plane than in the direction of the poles, so as to appear as a great mass of stars along its edge.

The nineteenth century saw the rise of astrophysics and the use of the spectroscope in unravelling the physical conditions of the stars. The classification of stars according to their spectral classes attained its most important form in the so-called Hertzsprung-Russell diagram in which the luminosities of the stars are plotted against the structural classes. The points are found to lie in a narrow belt running diagonally from the brightest stars to the faint red ones, now known as the mean sequence. This diagram has proved invaluable in the study of stellar evolution.

Our knowledge of the structure and size of the universe could only be obtained by the use of large telescopes and principally by the 100-in. telescope at Mount Wilson and the 200-in. telescope at Mount Palomar. They reveal that the Milky Way consists of hundreds of billions of stars arranged in a flattened disk so large that it would take light travelling at 186,000 miles a second 100,000 years to cross the disk. Herschel had long ago suspected that the nebulosities seen in the Milky Way might be systems of stars similar to our own, but lying outside it. His conjecture was amply confirmed by Hubble from his observations at Mount Wilson. Our nearest nebula, Andromeda, is two million light years away from us, while the farthest nobula so far photographed with the 200-in. telescope at Mount Palomar is about two thousand million light years away. Radio telescopes have probed even farther into space to distances of the order five thousand million light years. Within this great expanse there are probably thousands of millions of these galaxies the distribution of which appears to be uniform in space.

Early in 1930 an observation by an electrical engineer, Jansky, marked the beginning of the study of the new science of radio astronomy. He detected some radiation in the decimetre wave-length which he was convinced came from outer space since the signals he received were not observed at the same time on consecutive days but were observed $4 \mathrm{~min}$ earlier each day, corresponding to the lapse of a sidereal day instead of a solar day. Jansky's discovery did not occasion much enthusiasm at the time and it was left to an amateur, Reber, to confirm his conclusions. Later still it was recognized that radio signals could be picked up from regions of space farther away from us than would be possible by observations from optical telescopes. Some of the radiation is now known to originate in the interstellar gas, and a brilliant prediction by the Dutch astronomer van der Hulst that this was radiation of $21 \mathrm{~cm}$ wave-length emitted by hydrogen clouds in interstellar space was confirmed by his Dutch colleagues. By this discovery it was recognized that our galaxy has a spiral structure very much like that of the great A.ndromeda nebula.

Prof. Ferraro then referred to the first-fruits of space research and in particular the discovery of the highenergy particles trapped in the Earth's magnetic field and known as the van Allen radiation belt. This consists of two belts, the inner one, at about $2,000 \mathrm{~km}$ from the Earth, being quite stable and generally believed to be produced by neutron decay, while the outer belt, extending from three to five Earth radii or more from the Earth, consists for the most part of high-energy electrons. This is rather variable, especially during magnetic storms.

Recent flights by space probes have also shown the absence of a magnetic field on the Moon and Venus and the high temperature on this planet. In the foreseeable future it seems unlikely, however, that space probes could travel much beyond the confines of the Solar System and that, so far as could be seen, space exploration by probes and satellites was a limited venture. Further knowledge of the vast universe around us must still be derived from observation by conventional optical and radio telescopes.

Prof. Ferraro then briefly referred to cosmological theories which had been proposed and noted that there were, at the present day, two rival theories in the field, the evolutionary theory and the steady-state theory. 